\title{
First report on the occurrence of benzoxazinoids in an invasive weed plant, woolly cupgrass (Eriochloa villosa (Thunb./Kunth)
}

\author{
Peter Makleit ${ }^{1}$, Szilvia Veres ${ }^{2 *}$ and Arnold Szilágyi ${ }^{3}$
}

1 University of Debrecen, Faculty of Agricultural and Food Sciences and Environmental Management, Institute of Crop Sciences, Department of Applied Plant Biology; pmakleit@agr.unideb.hu

2 University of Debrecen, Faculty of Agricultural and Food Sciences and Environmental Management, Institute of Crop Sciences,Department of Applied Plant Biology; szveres@agr.unideb.hu

3 University of Debrecen, Faculty of Agricultural and Food Sciences and Environmental Management, Institute of Plant Protection, szilagyi.arnold@agr.unideb.hu

* Correspondence: szveres@agr.unideb.hu

\begin{abstract}
Woolly cupgrass (Eriochloa villosa /Thunb./ Kunth) is a common weed in East Asia and North America. This weed plant spreading quickly in Europa. There are several reasons for the successfulness, especially its germination properties. As other Panicoideae species contain benzoxazinoids it was supposed that woolly cupgrass also contains these chemicals. For this reason the benzoxazinoid content of plants at the stage of flowering was investigated. As it was supposed, woolly cupgrass contain benzoxazinoids, which is a novel occurrence of these chemicals in Poaceae family.
\end{abstract}

Keywords: benzoxazinoids; Eriochloa villosa, wolly cupgrass; new occurrence

\section{Introduction}

Woolly cupgrass (Eriochloa villosa /Thunb./ Kunth) is a common weed plant in East Asia. In the middle of the twentieth century it was appeared in North America, in the United States, especially as a corn weed. Soon it was spread and also appeared in the south part of Canada at the start of the twenty-first century. At the same time it was came out in Europe too (Romania, Ukraine, Hungary) [1]. In the last few years this problematic weed plant was found from other Western and Eastern European countries [2]. In Hungary there are numerous regions where this invasive plant was found [3]. The problems of controlling this annual weed originating from its seed germination properties, namely that the seeds emerge from deeper soil layers and long-continued time of the growing season [1]. In addition the plants are less susceptible for some herbicides used against other annual grass weeds in corn [4].

The successfulness of plant species can be originated from their ability to supress other plants development. For this purpose plants produce and exudate especially through their roots, so called allelopathic chemicals. Plants from Poaceae family use benzoxazinoids against their competitors and pests. Benzoxazinoids can be classify into three groups, so called lactams (such as: 2-hydroxy-1,4-benzoxazin-3-one: HBOA; 2hydroxy-7-methoxy-1,4-benzoxazin-3-one HMBOA, hydroxamic acids (such as: 2,4dihydroxy-1,4-benzoxazin-3-one: DIBOA; 2,4-dihydroxy-7-methoxy-1,4-benzoxazin-3one: DIMBOA) and benzoxazolines (such as: benzoxazoline-2-one: BOA; 6-methoxybenzoxazoline-2-one: MBOA) [5]. Woolly cupgrass is member of Panicoideae subfamily. Several genera of the same subfamily of Poaceae contain benzoxazinoids, like Coix, 
Echinochloa, Tripsacum and Zea [6]. Ten days old Echinochloa plants for example contained DIBOA in glycosidic form in amount of 194-267 $\mu \mathrm{g} \mathrm{g}^{-1}$ fresh weight [7]. Five week old Echinochloa crus-galli plants in turn contained DIMBOA and DIBOA in form of their glucosides, in amount of $8.7-18.85$ and $4.05-7.5 \mu \mathrm{g} \mathrm{g} \mathrm{g}^{-1}$ fresh weight respectively [8]. HMBOA was not demonstrated from this plant species. Corn and Coix spp. however contain HMBOA in considerable amount [9]. Up to now there is no data about the benzoxazinoid content of Eriochloa villosa which was investigated in our experiment.

\section{Materials and Methods}

Seeds of woolly cupgrass were collected from field grown plants in Hungary, in the region of Hajdúság, near to town Debrecen, in 2020. Ten seeds were shown at the $20^{\text {th }}$ of May, 2021, in $14 \mathrm{~cm}$ diameter pots, filled with universal soil for garden use, obtained from commercial trade. After germination 3 plants were left in each pot. We had independent four pots. The plants were grown in special growing house, on the open air. Water supply was applied to the $65 \%$ of the field water capacity, every two days. The sample collection was carried out at the start of flowering (Picture 1.).

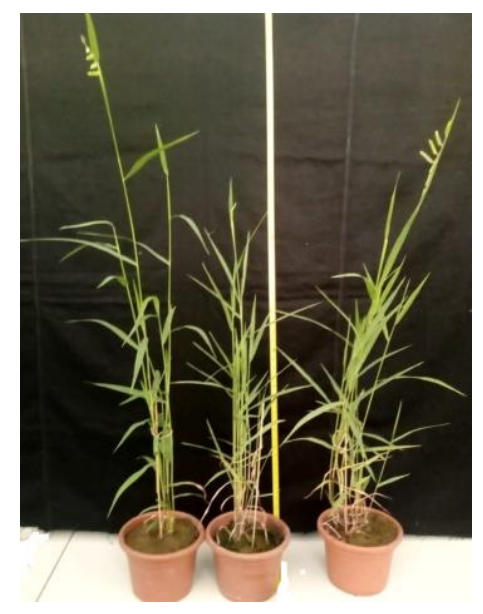

Figure 1. Woolly cupgrass plants at the stage of flowering

Its' date was the $2^{\text {nd }}$ of July, so the plants were 69 days (about 10 weeks) old at the time of sampling. The flag leaf, the last fully expanded upper leaf and the youngest parts of root was collected from four individual plants per pot. Four plants were used for measurements, each was grown in different pots. The fresh weight of samples were measured and stored in a deep-freezer at -80 Celsius degree until sample preparation.

The sample preparation and HPLC determination was carried out according to Lyons et al. [10]. DIMBOA and DIBOA standards were isolated from etiolated corn and rye seedlings by using the method of Hartenstein et al. [11]. HMBOA standard was synthetized and provided by Pierre Mateo (Universität Bern, Institute of Plant Sciences). The DIMBOA and DIBOA standards were checked and identified by their melting points and by ${ }^{1} \mathrm{H}$ NMR spectra recorded for $\mathrm{CD}_{3} \mathrm{OD}$ solutions. The applied equipment was Bruker $360(360 \mathrm{MHz})$ spectrometer. Chemical shifts were referenced to $\mathrm{CH}_{3} \mathrm{OH}(\delta 3.31 \mathrm{ppm})$. The melting point of DIMBOA and DIBOA were $168.0-169.0{ }^{\circ} \mathrm{C}$, and $163.5-165.0^{\circ} \mathrm{C}$ respectively. A Jasco type equipment and a reverse phase C18 column (Lichrospher RP18-5; 250 x $4.0 \mathrm{~mm}$ ) were used for HPLC measurements. Samples' volume was $20 \mu \mathrm{l}$. At the start and end of every set of measurements, solutions of pure DIMBOA, DIBOA and HMBOA were used as standards. The standard solutions were made from crystalline material. Repetition in case of all samples was 4 . The maximal concentrations of measured compounds were published. 


\section{Results and discussion}

The occurrence of benzoxazinoids was demonstrated in a new plant species - woolly cupgrass (Eriochloa villosa /Thunb./ Kunth) - by our laboratory. Table 1 demonstrates the measured maximal benzoxazinoid contents in different parts of woolly cupgrass plants.

Table 1. Maximal benzoxazinoid content of woolly cupgrass in different parts ( $\mathrm{mg} \mathrm{g}^{-1}$ fresh weight); (Root, Flag leaf, Last fully expanded leaf) $n=4$

\begin{tabular}{ccc}
\hline Organ/Benzoxazinoid & DIMBOA & HMBOA \\
\hline Root & 0.10 & 0.12 \\
Flag leaf & 0.17 & 1.61 \\
Last fully expanded upper & 0.19 & 0.85 \\
leaf & & \\
\hline
\end{tabular}

According to our results roots of unstressed plants contain DIMBOA and HMBOA at almost the same concentrations, while leaves contain higher amount of HMBOA than DIMBOA. These compounds are present in intact tissues in glycosidic form [6], but as a consequence of our sample preparation method, glycosidase enzymes released aglucones, which were measured and presented.

Compared to earlier results $[7,8]$ the measured concentrations are at the same range (data are not presented) than the concentrations in shoots of ten days old Echinocloa plants. The young parts of older plants can contain benzoxazinoids in as high concentration as young plant [12], and the examined shoot and root parts were the youngest parts of the plants. Pethö [8] measured benzoxazinoids in lower concentrations in five week old seedlings of barnyard grass, but the plant material was the whole shoot of the plants, not the only the youngest parts.

As it is well known, the distribution of various types of benzoxazinoids is vary amongst different species [13], so there is the possibility of variation even in a plant subfamily (Panicoideae).

As woolly cupgrass is an invasive plant, with high ability for spreading and high competition capacity, one of the reason of this plant's success can be the benzoxazinoids production, which allow the higher ability to tolerate both biotic and abiotic stress factors. Moreover the benzoxazinoids producing plants exudate these chemicals through their roots to the rhizosphere [12], and these exudates serve as allelochemicals, regulate the germination and growth of competing plant species.

Author Contributions: Conceptualization, P.M and A. SZ; methodology, P.M.; resources writingoriginal draft preparation, P.M.; writing - review and editing, SZ. V and A. SZ; supervision, SZ. V;

Funding: Please add: This research was funded by the HUNGARIAN GOVERNMENT, EFOP3.6.1-16-2016-00022, “Venture Catapult" project.

Data Availability Statement: Data available in a publicly accessible repository. The data presented in this study are openly available at [ㅇi] , reference number [reference number].

Acknowledgments: The authors acknowledge Pierre Mateo (Universität Bern, Institute of Plant Sciences) for providing HMBOA standard. The authors also acknowledge Andrea Balláné Kovács (University of Debrecen, Institute of Agricultural Chemistry and Soil Science) for providing plant growing facilities. 
Conflicts of Interest: The authors declare no conflict of interest. The funders had no role in the design of the study; in the collection, analyses, or interpretation of data; in the writing of the manuscript, or in the decision to publish the results.

\section{References}

1. Somogyi, N.; Szabó, L.; Dávid, I. Az ázsiai gyapjúfü (Eriochloa villosa /Thunb./ Kunth) megjelenése Hajdú-Bihar megyében. Agrártud. Közlem, 2011, 43., 119-123.

2. Follak, S.; Schwarz, M.; Essl, F. First record of Eriochloa villosa (Thunb.) Kunth in Austria and notes on its distribution and agricultural impact in Central Europe. BioInvasions Rec. 2020. 9/1, 8-16. https://doi.org/10.3391/bir.2020.9.1.02

3. Szilágyi, A.; Tóth T.; Radócz L. Az ázsiai gyapjúfü (Eriochloa villosa [Thunb.] Kunth) új előfordulása a Hajdúsági kistérség területén. Agrártud. Közlem., 2016, 71. 51-54. https://doi.org/10.34101/actaagrar/71/1572

4. Szilágyi, A.; Balogh, Z.; Dávid, I.; Szabó, L.; Radócz, L. Woolly cupgrass (Eriochloa villosa /Thunb./ Kunth), a recently occured invasive weed in Trans-Tisza Region and a trial for control in maize. J. Agric. Sci., 2015, 65, 53-57. https://ojs.lib.unideb.hu/actaagrar/article/view/1892

5. Tanwir, F.; Dionisio, G.; Adhikari, K.B.; Fomsgaard, I.S.; Gregersen, P.L. Biosynthesis and chemical transformation of benzoxazinoids in rye during seed germination and the identification of a rye Bx6-like gene. 2017, doi: 10.1016/j.phytochem.2017.04.020. Epub 2017 May 1. Erratum in: Phytochemistry. 2018 Jan;145:214. PMID: 28472715.Niemeyer, H. M. Hydroxamic acids (4-hydroxy-1,4-benzoxazin-3-ones), defence chemicals in the gramineae

6. Niemeyer, H. M. Cyclic hydroxamic acids (4-hydroxy-1,4-benzoxazin-3-ones) defence chemicals in gramineae.1988., Phytochem. 27, 3349-3358.

7. Pethő, M. A ciklikus hidroxámsavak előfordulása kakaslábfű fajokban. Bot. Közlem. 1993. a. 80/2, 191-197.

8. Pethő, M. Occurrence of cyclic hydroxamic acids in the tissues of barnyardgrass (Echinochlos crus-galli/ L./P.B.) and their possible role in allelopathy. Acta Agron. Hung. 1993 b., 42(3-4), 197-202.

9. Huang, C.; Wang, X.; Wang, R.; Xue, K.; Yan, F.; Xu, C. Distribution and variations of three 1,4-benzoxazin-3-ones in maize induced by the Asian corn borer, Ostrinia furnacalis (Guenée). Z Naturforsch C J Biosci. 2006., 61(3-4), 257-62. doi: 10.1515/znc2006-3-417. PMID: 16729586.

10. Lyons, P.C.; Hipskind, J.D.; Wood, K.V.; Nickolson, R.L. Separation and quantification of cyclic hydroxamic acids and related compounds by high-pressure liquid chromatography. J. Agric. Food Chem. 1988., 36, 57-60. https://doi.org/10.1021/jf00079a015

11. Hartenstein, H.; Lipmann, T.; Sicker, D. An efficient procedure for the isolation of pure 2,4-dihydroxy-7-methoxy-2H-1,4- benzoxazin-3(4H)-one (DIMBOA) from maize. Indian J. Heterocycl. Chem. 1992, 2, 75-76.

12. Wouters, F. C.; Blanchette, B.; Gershenzon, J.; Vassão D.Plant defense and herbivore counter-defense:benzoxazinoids and insect herbivore. Phytochem. Rev. 2016, 15:1127-1151. DOI 10.1007/s11101-016-9481-1.

13. Niculaes, C.; Abramov, A.; Hannemann, L.; Frey, M. Plant Protection by benzoxazinoids - recent insights into biosynthesis and function. Agronomy 2018, 8, 143. https://doi.org/10.3390/agronomy8080143 